\title{
SOME THOUGHTS RAISED BY MAGNA CARTA: THE POPULAR RE-ELECTION OF JUDGES
}

\author{
W. Hamilton Bryson *
}

I take as my text and begin with Chapter 29 of the final version of Magna Carta of $1225,{ }^{1}$ which reads as follows:

No free man shall be taken or imprisoned or disseised of any freehold or of liberties or free customs ... except by the lawful judgment ... of his peers or by the law of the land .. . to no one shall we sell, to no one deny or delay right or justice. ${ }^{2}$

This is said to be one of only three parts of the Great Charter still in force in Great Britain. But this is rightly so, for it is the heart and soul of the statute. ${ }^{3}$

This text ensures that a person's property, body, and reputation will not be taken away before and without a trial in a court of law in which the judge observes the law and the due process thereof. This requires hearing the evidence and the arguments of all of the parties, after which, the judge applies the law to the facts of a case in order to reach a decision. ${ }^{4}$

This is the rule of law. This is the foundation of civilization.

Consider the opposite of the rule of law. It is the rule of force. The rule of force is tyranny by the powerful, not by the just. It is

* Blackstone Professor of Law, University of Richmond School of Law. LL.D., 2013, University of Cambridge; Ph.D., 1972, University of Cambridge; LL.M., 1968, University of Virginia School of Law; LL.B., 1967, Harvard Law School; B.A., 1963, Hampden-Sydney College.

This essay was first presented at the Magna Carta anniversary symposium of the Baronial Order of Magna Charta on April 16, 2015, at The Cosmos Club, in Washington, D.C.

1. The original version of 1215 was immediately repudiated by King John with the consent of the pope. See W.H. Bryson, Papal Releases from Royal Oaths, 22 J. OF ECCLESIASTICAL HIST. 19, 21-22 (1971).

2. Sir J. Baker, The Legal Force and Effect of Magna Carta, in Magna CARTA: Muse \& MENTOR 65, 70 (Randy J. Holland ed., 2014).

3. See generally id. at 70-84 (discussing why chapter 29 is the key surviving provision of Magna Carta).

4. See id. at 71-75. 
where the big fish eat the little fish and it is simply because they can; they have the power to do it. The rule of law is that right makes might. Without the rule of law, there can be no human rights. Human rights are the rights of an individual asserted against everyone else, if needed, such as the freedom of religion and of no religion. By contrast, if might makes right, society slips into anarchy as power moves from one person or group of persons to another. Anarchy is the opposite of freedom for these reasons. I hope that we can agree that anarchy is bad and that the rule of law is good. And I hope that we can agree that the rule of tyrants who are above the law is bad and the rule of law is good.

Consider another opposite of the rule of law. It is the rule of no law, anarchy. Anarchy is where the tyrants who are powerful do whatever they please because they can. It is unpredictable, and, therefore, not even the tyrants are safe. Anarchy is the opposite of civilization.

The rule of law requires access to the courts of law, and Chapter 29 of Magna Carta requires it. ${ }^{5}$ The courts enforce the rule of law by putting it into effect by their due process, i.e., procedures for hearing the evidence and arguments of the parties before it. The procedure of the courts is the skeleton of the substantive law; the substance is the muscle of right.

The courts of law cannot function properly to administer the rule of law if they are not independent, independent not only of the political branches of the government but also of the will of the people. Human rights are not to be taken away by popular opinion or votes. Human rights are often unpopular with the majority of the people as well as with tyrants. A popular majority can act tyrannically and sometimes does.

The independence of the judiciary can be destroyed by financial corruption and by political intimidation. The focus of the remainder of my remarks is political control of judges. This is evil because it destroys the ability of the judges to administer the rule of law. Our federal and state constitutions all have checks and balances to prevent, or at least minimize, the political control of the judges. But most states provide for the popular election and reelection of the judiciary, ${ }^{6}$ and this power of control has no limita-

5. See id. at 84 .

6. See Fact Sheet on Judicial Selection Methods in the States, AM. BAR Ass'N, http:// 
tion whatsoever. The abuses come from the power to reelect or not to reelect a sitting judge.

The power of popular election and re-election of judges was not intended to oppress the judiciary. The original idea was that, as we have popular election of the other branches government, so there should be a democratic election of the judiciary as well. Historically, this system worked satisfactorily because, as a matter of professional courtesy, no one ran in opposition to the re-election of a sitting judge. However, since about forty years ago, this convention has no longer been observed.

The sad, shocking result has been the intimidation of judges by the press and by the general public. If a judge's application of the law in a particular lawsuit will cost votes and result in not being re-elected, this strikes at the independence of the judiciary, the foundation of due process and the rule of law.

Here are some examples of why the popular re-election of judges has become an evil thing.

One of the most notorious examples of judicial intimidation by the press was the prosecution of Dr. Samuel H. Sheppard of Cleveland, Ohio, for the murder of his socialite wife. ${ }^{7}$ The judge in the case was due for an immanent re-election, and the prosecutor was running for election to a different judgeship. ${ }^{8}$ Therefore, both needed the support of the press, and the press corp had decided that the defendant was guilty. ${ }^{9}$ The United States Supreme Court eventually set aside of the conviction because the public pressure of the press corp on the judge had denied the defendant his fundamental right of due process in an impartial court of law. ${ }^{10}$

There is another recent United States Supreme Court case that illustrates this problem. In a recent trial in West Virginia, the defendant corporation was ordered to pay the plaintiff $\$ 50$ million. ${ }^{11}$

www.americanbar.org/content/dam/aba/migrated/leadership/fact_sheet.authcheckdam.pdf (last visited Oct. 21, 2016) (noting thirty-nine states total hold partisan, nonpartisan, or uncontested retention elections for trial courts of general jurisdiction).

7. Paul Holmes, The Sheppard Murder Case 3-8 (1961); Cynthia L. Cooper \&

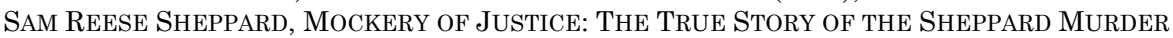
Case 14-19 (1995); James NefF, The Wrong Man: The Final Verdict on the Dr. SAM SHEPPARD MURDER CASE 56-57(2001).

8. Sheppard v. Maxwell, 384 U.S. 333, 341-42 (1966).

9. Id. at 362 .

10. Id. at $362-63$.

11. Caperton v. A.T. Massey Coal Co., Inc., 556 U.S. 868, 872 (2009). 
The defendant was going to and did appeal to the Supreme Court of Appeals of West Virginia. ${ }^{12}$ Before the appeal was to be heard, one of the justices of that court came up for re-election. ${ }^{13}$ A lawyer challenged that justice's retention, running a campaign for his seat on the court. The challenger and his re-election committee received several million dollars from one person, the chief executive officer and president of the defendant-appellant in the case mentioned. ${ }^{14}$ This was by far more money than from any other contributor to either judicial candidate and more than from all of the other contributors to both of them. The sitting judge was removed from the bench and the challenger was elected by a small majority. ${ }^{15}$ Shortly thereafter, the appeal by the major contributor's company, his employer, came before that court and before that new judge on a request for a reversal. The new judge refused to recuse himself. The court then, on a three to two vote, reversed the $\$ 50$ million verdict, the new judge casting the tie-breaking vote to reverse this large verdict and judgment against his benefactor's company. ${ }^{16}$ Had he recused himself, the verdict and judgment would not have been reversed. The United States Supreme Court set the West Virginia judgment aside on the ground that the failure to recuse allowed that judge to influence the outcome of the litigation in favor of his financial supporter and denied the appellee due process of the law because it appeared that the court was not neutral. ${ }^{17}$ The United States Supreme Court's holding was by a vote of five to four. ${ }^{18}$ An appellate court judge from Virginia said to me in a private conversation that she was shocked that it was not a unanimous decision, being such an egregious breach of judicial ethics.

A former student of mine who practices law in Richmond, Virginia, recounted to me that he was trying a case in West Virginia, and, during a recess, the bailiff said that the judge wished to see counsel in his chambers. When they went to see the judge, he asked for a contribution to his re-election fund. My friend refused to name the judge or say what he and the opposing counsel did.

\footnotetext{
12. Id. at 873 .

13. Id.

14. Id.

15. Id.

16. Id. at 874 .

17. Id. at $889-90$.

18. Id. at 871,890 .
} 
Another student of mine from Texas told me that her father was a trial court judge there. In one case, he ruled against a lawyer's motion in a completely routine case, and the lawyer went into a rage and started a campaign to defeat her father's reelection. The ground of the campaign was that he abused his children and was soft on criminals. His daughter, my student, said that this was totally false as to any abuse and, in fact, he sat in a civil court that lacked criminal jurisdiction. However, in spite of the falsehoods, the good judge was not reelected.

When driving through the state of Maryland, one sees huge, expensive billboards urging the re-election of someone as judge of a particular court. One knows that the judge cannot afford to pay for the billboard; so one wonders who did and why. The speculation does not lead to confidence in the judicial system in the state of Maryland.

There was a recent campaign for a judicial position in Maryland near the District of Columbia. One of the candidates campaigned with the promise that, if elected, she would impose the maximum sentence on every person convicted of drunk driving. A very distinguished judge from Northern Virginia opined in a presentation to a meeting of the Richmond Bar Association that, if this judicial candidate were elected, then she must recuse herself from every drunk driving case because she had committed herself to the sentence before hearing argument on its appropriateness. I do not know the outcome of the election, but the campaign promise itself impugned the integrity of the judicial process.

Justice Penny J. White, while a member of the Supreme Court of Tennessee, ruled against the death penalty as applied in a particular case. ${ }^{19}$ Her position was highly unpopular with the law and order and victims' rights element of her state; they clearly did not understand the subtle distinctions of the law that Justice White was applying. She was not reelected because of the legal position she had taken, even though she was part of a majority of the judges in the court's decision and her opinion was entirely rational. ${ }^{20}$

19. Dan Levine \& Kristina Cooke, Uneven Justice: In States With Elected High Court Judges, A Harder Line On Capital Punishment, Reuters (Sept. 22, 2015, 2:00 PM), http:// www.reuters.com/investigates/special-report/usa-deathpenalty-judges/.

20. State v. Odom, 928 S.W.2d 18, 33 (Tenn. 1996). 
Here are some random examples from Ohio, West Virginia, Texas, Maryland, and Tennessee. I am sure many others can be easily found elsewhere.

The desire to influence the outcome of litigation in one's own favor is, of course, only natural. It is, in fact, the purpose and goal of every lawyer's argument in court. But this is done according to the due process of the court. However, to attempt to influence the judge's decision, not by argument and evidence presented in open court, but by an appeal to the judge's sympathy for an unfortunate person or to corrupt the legal process by bribing him or her or appealing to a fear of not being reelected, this is the problem. All judges will be tempted to unworthy behavior, as they live in the same world as the rest of us; they should resist temptation to do evil, as we all should. Fortunately, they usually do. But we need to make it as easy as possible for them to do so. The one thing that can and should be done is to remove the fear that an upright and honest judge has in an insecure system of judicial tenure that requires re-election by a popular vote, which must be subject to irrational political pressures. Where popular re-election of the judiciary interferes with a judge's application of the law, the rule of law itself is defeated.

The problem, therefore, is to find a workable way of protecting the good judges and of removing the bad ones. The solution of the English and the American federal systems is to have judges sit during good behavior, which means in effect for life because it takes a judicial proceeding in a court of law to prove bad behavior. Virginia and some few other states protect sitting judges by having the periodic re-election done by the legislature. This provides an effective shield against misdirected popular opinion. However, the popular vote for re-election of sitting judges is the norm for state judiciaries.

The conclusion that comes to mind to correct this is to amend the thirty-nine state constitutions that require the popular reelection of judges to find another method of removing bad judges. While it may be unpalatable to the press corps, the politicians, and petty tyrants, it is necessary to preserve the rule of law, which is the foundation of our liberty. This is the requirement of the spirit of Magna Carta.

Democracy, freedom, and the rule of law we have, more or less, but we need to make things better for ourselves and for our nation. We must strive for improvement, and we cannot take for granted what we have. 